\title{
STRATEGI MANAJEMEN KEUANGAN DALAM RUMAH TANGGA (BERBASIS EKONOMI SYARIAH )
}

\author{
ARNESIH \\ Pendidikan Sejarah, FKIP-UNRIKA \\ Email: Arnesih_siti@yahoo.com
}

\begin{abstract}
Abstrak
Perekonomian yang terjadi akhir-akhir ini membuat pusing kepala terutama para ibu rumah tangga yang harus bijak dalam mengelola keuangan. Hal ini akibat naik turun nya harga kebutuhan pokok. Dari pernyataan di atas, penulis bermaksud berbagi ilmu untuk menjaga kesetabilan keuangan dalam rumah tangga. Permasalahan dalam penelitian ini adalah seputar kajian tentang pengelolaan keuangan rumah tangga menurut ajaran Islam. Penelitian ini menggunakan pendekatan kualitatif dengan metode deskiptif. Teknik analisis yang digunakan adalah analisis deskriptif dan analisis isi. Hasil penelitian ini diarahkan pada pembinaan kepribadian terhadap manajemen keuangan setiap rumah tangga muslim, pengembangan manajemen keuangan secara Islami, pengembangan pengamalan ajaran Islam khususnya dibidang ekonomi dan keuangan, dan pengembangan sosialisasi dan penyampaian kepada orang lain,

Kata Kunci: manajemen keuangan, rumah tangga, ekonomi syariah

Economy happened lately create headaches especially housewives who should be wise in managing finances. This is due to the up and down its prices of basic necessities. From the above statement, the authors intend to share knowledge to safeguard financial stability in the household. The problem in this research is about the study of household financial management according to the teachings of Islam. This study used a qualitative approach with the method descriptively. The analysis technique used is descriptive analysis and content analysis. Results of this research is directed to the personality development of the financial management of each household Muslim, Islamic development financial management, development of practice of the teachings of Islam, especially in the field of economics and finance, and the development of socialization and transmission to others, others.
\end{abstract}

Keywords: financial management, household, Islamic economics 


\section{A. Pendahuluan}

Gejolak perekonomian yang terjadi akhir-akhir ini membuat pusing kepala terutama para ibu rumah tangga yang harus pandai-pandai dalam mengelola keuangan. Hal ini karena terjadi akibat naik turun nya harga kebutuhan pokok , meskipun harga BBM turun, tetapi tidak mempengaruhi terhadap turunya harga kebutuhan pokok .

Dari pernyataan hal tersebut penulis bermaksud berbagi ilmu guna menjaga kesetabilan keuangan dalam ruamah tangga. Sebagai salah satu bentuk kepedulian dalam ajaran Islam ada suatu sistem yang harus dijalankan sesuai dengan syariat, mengingat bahwa Agama Islam adalah agama universal yang mencakup berbagai aspek baik sosial, politik, budaya, dan ekonomi. Semua telah diatur di dalam ajaran Islam. Oleh karena Islam adalah Agama Rahmatan lilalamin ( membawa kebaikan, kesejahteraan, dan kebahagiaan dunia dan akherat ).

Permasalahan dalam penelitian ini adalah seputar kajian tentang pengelolaan keuangan rumah tangga menurut ajaran Islam. Permasalahan tersebut dirumuskan dalam pertanyaan: ( 1 ) Apa tujuan dari berumah tangga? ( 2 ) bagaimana cara mengelola keuangan secara syar’i ( 3 ) Metode apa yang digunakan dalam penelitian ini? .

Penelitian ini menggunakan pendekatan kualitatif dengan metode deskiptif. Teknik analisis yang digunakan adalah analisis deskriptif dan analisis isi. Adapun tahap penelitian yang dilalui adalah ( 1 ) orentasi, persiapan dan studi pendahuluan (2) Tahap pelaksanaan penelitian yang dilakukan adalah studi literature dan (3) laporan. Hasil penelitian ini diarahkan pada (1) Pembinaan kepribadian terhadap manajemen keuangan setiap rumah tangga muslim, (2) pengembangan manajemen keuangan secara Islami (3) pengembangan pengamalan ajaran Islam khususnya di bidang ekonomi dan keuangan , (4) pengembangan sosialisasi dan penyampaian kepada orang lain.

Rekomendasi diarahkan kepada (1) Manajemen keuangan pada setiap rumah tangga muslim tidak akan berhasil secara optimal dan maksimal jika setiap muslim hanya mengetahui ajaran Islam hanya diseputar ibadah mahdhoh saja ( seperti sholat,zakat, 
puasa, haji, dan mendikotomi Islam dan pengetahuan . (2) perlunya mengetahui bahwa ajaran Islam juga mengajarkan perekonomian, bahkan perekonomian dalam rumah tangga yang islami, (3) perlunya peran serta ulama dan umara agar menerapkan sistem sistem manajemen keuangan secara syariat, dan mendorong berdirinya infrastruktur perekonomian syariah.

\section{B. Latar Belakang Masalah}

Tujuan dalam rumah tangga Islam salah satunya adalah membentuk keluarga sakinah mawadah warahmah yaitu mencari kebahagiaan kesejahteraan dan keselamatan dunia dan akherat dalam Ridho Allah, oleh karna itu ketika seorang muslim memutuskan untuk menikah maka segala konsekwensi akan dimintakan pertanggungjawabanya baik dunia maupun akherat, oleh karna itu tujuan menikah adalah :

1. Secara umum perekonomian juga salah satu hal yang dikembangkan dari ajaranajaran agama islam yang terdapat dalam Al-quran dan as-Sunnah.

2. Salah satu tujuan dalam berumah tangga mencari ridho Allah untuk mencapai kebahagiaan dunia akherat, melanjutkan keturunan

Dari karakteristik tersebut diatas, maka dalam pengelolaan keuangan tidak hanya sekedar transfer informasi tentang perekonomian dari sebuah rumah tangga, tetapi harus menjadi suatu proses pembentukan kepribadian yang berkarakter. Pengelolaan ini mempunyai tujuan membentuk manusia yang beriman dan bertaqwa serta menjalankan kehidupan yang sesuai syariat Islam. 


\section{Rumusan Masalah}

Untuk lebih terfokusnya pembahasan ini maka penulis merumuskan bahwa yang menjadi masalah dalam penelitian ini seputar perekonomian syariah dalam sebuah rumah tangga yang meliputi:

1. Apakah ajaran Islam mengatur perekonomian?

2. Bagaimanakah cara mengelola keuangan secara syariah?

3. Apakah keuangan rumah tangga anda dalam keadan sehat?

\section{Tujuan Penulisan}

Penulisan ini bertujuan untuk mengetahui cara pengelolaan keuangan yang meliput:

1. Untuk mengetahui manajemen keuangan dalam rumah tangga Islami

2. Untuk mengetahui Strategi pengelolaan keuangan dalam rumah tangga Islami

3. Untuk mengetahui kondisi kesehatan keuangan rumah tangga

\section{E. Manfaat Penelitian}

Adapun manfaat yang diharapkan dari penulisan ini dapat bersifat praktek dan teoritik sebagai berikut:

1. Secara teoritik, hasil penulisan ini dapat menjadikan bahan kajian dalam materi manajemen keuangan yang berbasis syariah

2. Membantu mensosialisasikan manajemen keuangan berbasis syarah, khususnya bagi yang beragama Islam umumnya bagi yang ingin mengetahui strategi keuangan dalam rumah tangga

3. Secara praktik, dapat membantu para ibu rumah tangga yang masih bingung dalam mengelola keuangan dikarnakan tidak menggunakan manajemen strategi keuangan, sehingga pendapatan berapapun yang diterima tak pernah cukup apalagi ditabung. 


\section{F. Metode Penelitian}

Penelitian ini diorentasikan untuk mengkaji bagaimana mengelola keuangan dalam sebuah rumah tangga yang Islami. Penelitian ini bersifat kualitatif dengan menggunakan metode deskriptif. Dalam penelitian ini, untuk menemukan teori-teori baku yang digunakan sebagai petunjuk arah dalam menganalisis data yang ditemukan, kemudian dikategorisasi dan ditafsirkan dengan menggunakan perspektif dengan menggunakan analisis documenter.

\section{G. Kajian Teori}

Para ahli telah banyak mendefinisikan perihal ilmu perekonomian salah satunya menurut, untuk memberikan pengertian yang lebih jelas, maka berikut ini disampaikan beberapa definisi ekonomi Islam menurut Anto ( 2003) sebagai berikut:

1. Menurut stoner, ilmu manajemen merupakan proses dalam membuat suatu perencanaan pengorganisasian, pengendalian serta memimpin berbagai usaha dari anggota entitas/organisasi juga mempergunakan semua sumberdaya yang dimiliki untuk mencapai tujuan yang ditetapkan

\section{Pengertian Strategi}

Kata "strategi” berasal berasal dari bahasa yunani "strategos” yang berasal dari kata stratus yang berarti militer dan Ag yang artinya memimpin. Strategi dalam kontek awalnya ini diartikan sebaga igeneralship atau sesuatu yang dikerjakan oleh para jendral dalam membuat rencana untuk menaklukan musuh dan memenangkan perang (setiawan hari purnomo, $4: 1999$ )

3. Pengertian ekonomi Syariah

1. Ekonomi Islam adalah ilmu yang mempelajari masalah-masalah ekonomi masyarakat dalam perspektif nilai-nilai Islam ( Manan, 1993:18) 
2. Ekonomi Islam didefinisikan sebagai cabang ilmu yang membantu merealisasikan kesejahteraan manusia melalui alokasi dan distribusi sumber daya yang langka, yang sejalan dengan ajararan Islam, tanpa membatasi kebebasan individu ataupun menciptakan ketidak seimbangan makro dan ekonomi logis (Chapra,1996:33).

3. Ekonomi Islam adalah tanggapan pemikir-pemikir muslim terhadap tantangan ekonomi pada zamannya. Dalam upaya ini mereka dibantu oleh Al-qur'an dan Hadits, serta alasan dan penglaman (Siddiqi,1992:69)

4. Ekonomi Islam adalah suatu ilmu aplikasi petunjuk dan aturan syariah yang mencegah ketidak adilan dalam memperoleh dan menggunakan sumber daya material agar memenuhi kebutuhan manusia dan agar dapat menjalankan kewajibannya kepada Allah SWT dan masyarakat (Hasanuzzaman,1984:18).

\section{H. Pembahasan}

Membicarakan keuangan dalam rumah tangga merupakan hal yang sangat penting guna mengetahui apakah pereokomian rumah tangga kita termasuk ekonomi sehat atau tidak? Apakah pengelolaan keuangan rumah tangga kita sudah sesuai syariah?? setidaknya terdapat sebuah pertanyaan yang perlu direnungkan. Yang ideal mestinya kedua aspek itu diintegrasikan menjadi satu pendekatan yang utuh sekalipun pada prakteknya banyak kendala yang harus diselesaikan , karena setiap pilihan yang diambil akan berimplikasi pada metodologi serta target akhir yang hendak dicapainya, yaitu kesejahteraan yang diridhoi Allah SWT.

Pada hakekatnya rizki pemberian Allah merupakan amanah yang harus dijalankan sesuai dengan pungsinnya, baik dalam penglolaan maupun dalam menjaganya seperti yang tercantum dalam qura'an surat Al-baqarah ayat 265 yang artinya : “ dan perumpamaan orang-orang yang membelanjakan hartanya karena mencari keridhoan Allah dan untuk keteguhan jiwa mereka, seperti sebuah kebun yang terletak didataran tinggi yang disiram oleh hujan lebat maka kebun itu menghasilkan buahnya dua kali 
lipat, jika hujan lebat tidak menyiraminya, maka hujan gerimis (pun memadainya) Dan Allah maha melihat apa yang kamu perbuat.

Maksud ayat tersebut menjelaskan bahwa rizki adalah pemberian Allah, maka jika kita menggunakannya sesuai fungsinya dijalan Allah, maka Allah akan menambah nya berlipat ganda, maka biasakanlah untuk menyisihkan keuangan kita minimal dua setengah persen untuk diinfakan dijalan Allah, lalu pergunakan keuangan itu sesuai kebutuhan dan rencanakan sesuai target. Tetapi masih banyak orang yang belum menjalankan strategi keuangan dengan baik dan benar. Hal itu karena masih ada orang yang mendikotomikan ajaran Islam.

Ada tiga hal yang saya anggap kurang tepat dalam pengelolaan keuangan dalam rumah tangga pertama, Pengelolaan keungan dalam rumah tangga dipisahkan dengan ajaran Islam, seolah -olah islam tidak mengajarkan bagaimana cara mengelola keuangan dalam rumah tangga . Kedua Tidak memiliki strategi pengelolaan keuangan dalam Rumah tangga Islami , sehingga sering tidak ditemukan hal-hal yang prinsipil yang seharusnya dipelajari lebih awal, malah terlewatkan, bahkan ini terlebih jelas lagi terlihat implementasi manajemen keuangan dalam rumah tanga yang dianggapnya sebagai puncak atau inti agama, maka islam seakan diidentikan dengan paham keagamaan yang bersifat dikotomi. Ketiga kurangnya penjelasan yang luas dan mendalam serta kurangnya penguasaan simantik dan generik atas istilah - istilah kunci dan pokok dalam ajaran agama sehingga sering ditemukan penjelasan yang sangat jauh dan berbeda dari makna yang sebenarnya, Hal semacam inilah yang membuat umat Islam terkadang kaku dalam menjalankan syariat islam, bahkan syariat Islam dianggap suatu hal yang memberatkan ini semua akibat dari cara penyampaian ajaran Islam yang kurang tepat, padahal kalaulah semua umat islam mengetahui bahwa ajaran islam adalah ajaran yang universal yang menyangkut kebahagian dunia dan akherat keselamtan dunia dan akherat, hal inilah sebenarnya yang diinginkan oleh semua orang.

\section{Pengelolaan Keuangan Dalam Rumah Tangga}


2. Pendapatan/pemasukan/ gaji

2. Pengeluaran

a. kebutuhan pokok harian $50 \%$

b. Zakat/Infak/Sodakoh 2 1⁄2\% ( jika zakat, jika infak sodakoh seikhlasnya)

b. kredit $20 \%$

c. investasi $20 \%$

d. UGD (uang gawat darurat) $7 \frac{1}{2} \%$

\section{Pengaturan dan Pengalokasian Keuangan}

Contoh :

Pemasukan /bulan 3.000.000

Pengeluaran :

1. Kebutuhan pokok $50 \%=1.500 .000$

2. Zakat/infak/sodakoh $=75.000$ ( jika zakat, lihat nasab dan khaulnya, jika infak dan sodakoh seikhlasnya

3. Kredit $20 \%=600.000$

4. Investasi $10 \%=300.000$

5. Uang Gawat darurat $71 / 2 \%=225.000$

6. Total pengeluaran $100 \%$

\section{Strategi Pengaturan Kebutuhan Pokok}


- Kebutuhan pokok $/ 1.500 .000: 30$ hari $=50.000 /$ hari

- 50.000 adalah untuk uang jajan anak, transport dan belanja

- 75.000 adalah zakat atau disesuaikan dengan syariatnya, sesuai nisab, dan khaulnya, tetapi jika sodakoh atau infak maka dikeluarkan sesuai keikhlasan

- Kredit/600.000 : bayar listrik, air, tagihan lainnya

- Investasi/300.000 tabungan pokok

- UGD/300.000 untuk jaga jaga kalo ada kebutuhan mendadak

\section{Mengukur Kesehatan Keuangan Rumah Tangga}

Pada dasarnya mengukur kesehatan keuangan Rumah tangga adalah bagaimana cara kita berkomitmen untuk melaksanakan apa yang telah direncanakan diatas, karena jika kita tidak bisa komitmen terhadap keuangan Rumah tangga, maka keuangan rumah tangga dalam keadaan sakit, jika kita dapat melaksanakan perencanaan keuangan sesuai yang kita rencanakan seperti contoh diatas maka keuangan Rumah tangga kita dalam keadaan sehat.

Allah swt, telah memberikan kecukupan harta pada manusia sesui firman Nya dalam qur'an surat adhuha ayat 8 yang artinya "Dan Dia mendapaitimu sebgai seorang yang kekurangan, lalu Dia memberikan kecukupan ( QS, Adh-Dhuha: 8).

\section{Kiat-kiat Menjaga Keutuhan Keuangan Keluarga}

- Rencanakan anggaran belanja harian, mingguan, bulanan dan tahunan

- Belanjalah sesuai kebutuhan saja

- Prioritaskan kebutuhan yang lebih penting

- Mencari peluang usaha

- Memanfaatkan sumberdaya manusia 
- Memanfaatkan sumberdaya alam

\section{Kesimpulan}

Berdasarkan data yang dibahas diatas, penulis menyampaikan bahwa secara umum manajemen keuangan dalam rumah tangga sangat penting, karena hal tersebut salah satu penentu kecukupan keuangan keluarga yang dimiliki oleh setiap rumah tangga, dan ukuran kesehatan keuangan keluarga. dari manajemen keuangan rumah tangga ini kita dapat melihat apakah keuangan keluarga kita dalam keadaan sehat atau sakit

1. Pentingnya mengelola keuangan dalam sebuah rumah tangga secara Islami

2. Mengetahui keberadaan ekonomi yang sehat dalam sebuah rumah tangga

3. Mengelola pemberian Allah sesuai dengan Fungsinya

Saran-saran

1. Setiap rumah tangga muslim disarankan mengelola keuangan secara syar’I

2. Jagalah kesehatan ekonomi keluarga, untuk mendapatkan Ridho Allah SWT

3. Menjalankan perintah Allah dan menjauhi larangannya, untuk kemaslahatan keluarga dan menjadikan keluarga sakinah mawaddah warohmah 


\section{DAFTAR PUSTAKA}

Al-Malik Fadh Fli Thibaat. Al-Qur.an dan terjemah: Saudi : Depag Saudi

Anto, MB, Hendrie. Pengantar Ekonomi Mikro Islami. Yogyakarta: Ekonisia

Buchari Alma, Donni Juni Priansyah. 2009. Manajemen Bisnis Syariah.Bandung: Alfabeta

Daud Vicary, Keon Chee. Buku Pintar Keuangan Syariah. 2012: Jakarta: Zaman

Jaka Isgiarta. 2009. Teori Akutansi dan Laporan Keuangan Islami.Semarang: UNDIP

Mannan, Abdul. 1993. Teori dan Praktek Ekonomi Islam. Yogyakarta: PT Dana Bakti Wakaf

Setiawan, Zulkieflimansyah. 2007. Manajemen Strategi. Jakarta: FE UI

Sholahuddin. 2007. Asas-asas Ekonomi Islam: Jakarta: Raja Grafindo Persada 